Multinational Corporations as Catalyst for Industrial Development: The Case of Poland

\author{
By: Carlo Altomonte and Laura Resmini
}

Working Paper No. 368

February 2001 


\title{
Multinational Corporations as Catalyst for Industrial Development:The Case of Poland
}

\author{
by Carlo Altomonte ${ }^{a}$ and Laura Resmini ${ }^{b}$
}

February 2001

\begin{abstract}
In a recent model Markusen and Venables (1999) describe the conditions under which foreign direct investments (FDI) can act as a catalyst for local industrial development. We apply this framework to the case of Poland, allowing for the entry of multinationals in both intermediates and consumption goods industry. We check these assumptions against empirical evidence, exploring agglomeration patterns of multinational and domestic firms at the regional level, and constructing an econometric model able to measure the interactions between the two classes of firms. We find evidence going in the direction of both direct spillovers and backward and forward linkages between domestic and multinational firms.
\end{abstract}

JEL classification: F12, F15, F21, P20

Keywords: economic geography, FDI, transition economies

${ }^{a}$ ISLA-Bocconi University, Milan and LICOS Centre for Transition Economics, KUL, Leuven

${ }^{\mathrm{b}}$ ISLA-Bocconi University, Milan

Contact:

Laura Resmini, Via Gobbi 5, ISLA-Università Luigi Bocconi, 20136 Milano, Italy

Tel: +39.02.5836.5409; Fax: +39.02.5836.5439; email: laura.resmini@uni-bocconi.it

(*) The authors wish to thank the participants of the Phare ACE Project on "The impact of EU Foreign Direct Investment and Trade on Firm Level Restructuring in Central and Eastern Europe" (Ref.: P97-8138-R) for helpful comments. The usual disclaimer applies. 


\section{Multinational Corporations as CATAlyst For Industrial Development. The Case of Poland}

\section{Introduction}

One of the main political and economic events in the next years will be the accession of some of the Central and Eastern European Countries (CEECs) to the European Union (EU). This process started with the fall of the Berlin Wall in 1989 and was followed by the transition of those countries from a socially-planned to a market economy, a phenomenon receiving widespread attention.

Among economists and political scientists a whole series of theories dedicated at analysing and predicting the path of such a transition have been developed (Blanchard, 1997; Repkine and Walsh, 1999); several EU Institutions are devoting significant resources to finance the set up of market structures in those countries in light of their accession, while multinational enterprises (MNEs), mainly European, have already acquired significant market shares in different industrial sectors of the CEECs ${ }^{1}$. In light of these processes, it is therefore interesting to explore the ways in which the industrialisation of the main CEECs has developed during the transition towards a market economy and the role played by MNEs with this respect, since in these countries, burdened with the legacy of large and obsolete state owned enterprises (SOEs) and distorted industrial structures, foreign investments can play an important role as tools of economic development and industry restructuring.

At the theoretical level, there is a reasonable agreement that MNEs can play a leading role as an agent of change. The creation of linkages and spillovers with local suppliers, superior technological content, marketing and management skills, result in higher productivity and technical efficiency, able to stimulate local rivals to a higher rate of innovation. Current foreign investments may also have a demonstration effect on other potential investors (Blomstrom and Kokko, 1997). MNEs, however, can also affect the entire structure of the industry by changing supply and demand conditions in a number of related industries. They may modify competitive conditions, damaging domestic industries in one sector but benefiting firms in other downstream sectors through price reduction and forward linkages to customer firms, or increasing the demand for local inputs and strengthening domestic supply industries through backward linkages. These linkages, in turn, may feed other local firms through spillover effects, hence generating endogenous growth (Markusen and Venables, 1999; Borensztein et al., 1998). Obviously, the magnitude and the sign of these effects may vary in relation to the characteristics of the countries/regions involved, the strategies followed

\footnotetext{
${ }^{1}$ Alessandrini (2000) provides a complete survey of this phenomenon.
} 
by MNEs and the characteristics of the industry in which foreign firms operate, thus resulting in different net effects (Aitken and Harrison, 1999).

In this paper we will therefore try to understand whether and to what extent Western European firms may act as a catalyst for local industrial development. At this purpose, we will apply to the case of Poland, the biggest and one of the most advanced accession countries, a theoretical model developed by Markusen and Venables (1999), discussed in Section 2 of the paper and modified in order to take into account the transition experience of Poland. Section 3 shows some static evidence of the phenomenon, presenting patterns of specialisation of multinational enterprises in Poland relative to domestic firms, with a regional and industry dimension. Section 4 develops and tests an econometric model able to measure the interactions between the two classes of firms. Section 5 concludes with some policy implications.

\section{Theoretical background}

The increasing evidence of large flows of intra-industry trade, in contrast with the predictions of the traditional trade theory, and the existence of similar regions with very different production structures, has brought economists to develop models of trade which could account for those findings, therefore introducing the hypothesis of increasing returns and imperfect competition. Within this theoretical framework, it is possible to explicitly model some of the aggregation forces already listed by Marshall (1890) under three headings: technological externalities, labour market pooling and intermediate goods supply and demand (pecuniary externalities).

These models, known under the headline of "New Economic Geography" (NEG), try to formalise the phenomenon of self-reinforcing cumulative causation that can lead very similar regions - in terms of their underlying structure - to endogenously differentiate into rich "core" regions and poor "peripheral" zones ${ }^{\mathrm{Z}}$.

When applying the general results of the NEG literature to the case of transition countries, it is however necessary to take into account the causes and patterns of the transition process and in particular the nature of the evolution of firms' activities in the area. In fact, there is nowadays a growing empirical evidence on the fact that the industrialisation process of the CEECs has been strongly influenced by the presence of Western multinational enterprises ${ }^{3}$. As a result, it seems appropriate to analyse the geography of industrial activities in the area using a model that not only considers the role of FDI, but goes also beyond simple country-level dynamics, exploring regional and industry patterns of agglomeration of firms.

\footnotetext{
${ }^{2}$ See Ottaviano and Puga (1998) for a survey of these models.

${ }^{3}$ See Repkine and Walsh (1999), Konings (2000).
} 
At this purpose, Markusen and Venables (1999) have recently shown the conditions under which MNEs can act as a catalyst for industrial development, leading to mechanisms of dynamic cumulative causation in the activities of domestic firms, generating therefore local agglomeration patterns.

Markusen and Venables start from a world where three kinds of firms are present: multinational $(m)$, domestic $(d)$ and foreign $(f$, i.e. exporting to the local markets) firms. Thanks to a standard Dixit-Stiglitz product differentiation hypothesis, they assume firms to be symmetrical within types, except for the fact that each produces a slightly different variety of product, being therefore a monopolist over its own variety $\$$ There is a single domestic economy and two monopolistically competitive industries: a downstream industry ( $c$, consumption) and an upstream industry ( $i$, intermediates). In the Markusen and Venables framework, consumer goods can be supplied by all three types of firms, while intermediates, being non-tradable, can be supplied only by domestic firms 5 .

However, the hypothesis relative to the intermediate industry is particularly restrictive when matched with the empirical evidence ${ }^{6}$, therefore, we have considered the Markusen and Venables framework allowing for multinational firms to be present also in the intermediate sector. As a result, there are five types of firms in the model. We indicate the total number of each type of firms operating in the host economy as follows:

domestic firms in $i$-industry:

multinational firms in $i$-industry:

domestic firms in $c$-industry:

multinational firms in $c$-industry:

foreign exporting firms in $c$-industry:

$$
\begin{aligned}
& n_{i}^{d} \\
& n_{i}^{m} \\
& n_{c}^{d} \\
& n_{c}^{m} \\
& n_{c}^{f}
\end{aligned}
$$

Our additional assumptions further adds on the analytical complexity of the model, leading to different patterns of possible agglomeration effects in a given economy. However, being the paper aimed at exploring the empirical evidence of those effects, any possible theoretical solution would have implied unrealistic assumptions. As a result, we have decided to work only on the conclusions of the Markusen and Venables model, adding some hypotheses on the effects of an entry of multinationals in the $i$-industry (i.e. an increase in

\footnotetext{
${ }^{4}$ An implication of this standard framework in NEG models is that it is able to take into account intra-industry trade.

${ }^{5}$ Rodriguez-Clare (1996) in a similar theoretical framework assumes that firms can gain access to intermediate goods produced outside the home country by becoming multinationals, i.e. by establishing headquarters in the home country and production plants in the host economy.

${ }^{6}$ Markusen and Venables (1997) already developed a model with MNEs operating in both intermediates and consumption goods industries, although not fully exploring possible catalyst effects arising within this framework. Alessandrini (2000) provides empirical evidence for the presence of MNEs in both intermediate and consumption goods industries in the CEECs.
} 
$n_{i}^{m}$ ), and leaving to other lines of research the development of a full theoretical model related to these issues.

\subsection{The entry of multinationals in the downstream industry}

An exogenous increase in $n_{c}^{m}$ affects the host country's industrial structure in two ways (Fig. 1a): first of all, there is a standard product competition effect, according to which the increased volumes available for consumption depress the price of the $c$-goods, leading to a reduction of profits of the domestic firms operating in the $c$-industry, hence to the exit of part of them and a reduction in their number, $n_{c}^{d}$. Secondly, there is a backward linkage effect: multinationals may raise the total demand for intermediates, increasing therefore the domestic firms' profits in the $i$-industry. This, in turn, can lead to an increase in the number of domestic firms operating in the $i$-industry, $n_{i}^{d}$, as postulated by Markusen and Venables.

The increase of demand faced by $i$-type domestic firms is such to create a forward linkage effect: given the assumption of downward sloping average cost curves, the increased production of the domestic firms in the $i$-industry will be undertaken at greater levels of efficiency, thus resulting in increased volumes of the available intermediates at lower prices. This will have a positive effect on the profitability of domestic firms operating in the $c$ industry, and would result at the end in an increase of the number of these firms, $n_{c}^{d}$.

At this stage, the effect of the entry of $c$-type MNEs on the total number of domestic firms operating in the economy, that is, $n_{i}^{d}+n_{c}^{d}$, leads to an a priori undetermined outcome. In order to end up with a catalyst effect, it is in fact necessary that either one condition is matched: i) MNEs use local intermediates more intensively than the domestic firms they displace in the $c$-industry; or ii) MNEs displace only foreign firms, with no effects on domestic firms

If one of these conditions occurs, the overall increased number of $c$-types domestic firms will increase the demand for intermediates, which will further contribute to the efficiency of $i$ type firms, creating therefore a mechanism of self-reinforcing cumulative causation.

[Figure 1 about here]

\subsection{The entry of multinationals in the upstream industry}

\footnotetext{
${ }^{7}$ This would happen if one accepts the controversial hypothesis of FDI and trade as substitute.
} 
Our additional assumption of the possibility of an entry of MNEs also in the $i$-industry generates a more complex set of interlinkages among multinationals and domestic firms.

First of all, we can apply the same logic as before (Fig. 1b). The entry of a multinational firm in the $i$-industry (increase in $n_{i}^{m}$ ), thanks to the higher efficiency reached in the $i$ industry characterised by increasing returns to scale, can make more profitable the production of $c$-goods, thus increasing $n_{c}^{d}$ through forward linkages; the increased demand of intermediates so generated creates a backward linkage effect, stimulating production by domestic firms in the same industry (increase in $n_{i}^{d}$ not displaced by product competition effects generated by the entry of $i$-type MNEs); the subsequent lower cost of intermediates in turns has again positive effects on $n_{c}^{d}$, hence generating a mechanism of cumulative causation, leading to the agglomeration of economic activities and as a result to a catalyst effect of FDI over the local economy.

However, the simultaneous presence of multinationals and domestic firms in both industries, may also reduce, eliminate or even turn negative the catalyst effect. The entry of $c$ type MNEs can lead to an increase in the number of multinational firms operating in the intermediate industry, $n_{i}^{m}$, rather than an increase in the number of domestic firms in the

same industry, $n_{i}^{d}$ (Fig. 1c), as well as an increase in $n_{i}^{m}$ may positively affect multinationals rather than domestic firms operating in the downstream industry (Fig. 1d). Taking this logic to the limit, there could be an equilibrium outcome where the selfreinforcing agglomeration pattern accrues only to multinational firms, thus generating a full crowding out of domestic production.

In conclusion, the dynamic interaction of domestic and multinational firms may arise several outcomes, depending on the starting conditions, the extent of displacement of domestic firms by multinational ones (a function of the degree of use of local intermediates by multinational firms and of the incumbent market structure), and the shape of the production function eventually yielding increasing returns to scale. In order to get a clear understanding of the phenomenon in the case of a transition country, it seems therefore appropriate to start from the empirical evidence available on those effects, combining it with the developed theoretical framework in order to derive an econometric model able to pinpoint the significant interactions arising among firms. The remaining of the paper is devoted to this exercise.

\section{The geography of FDI: a brief description}

In this section we examine the spatial and sectoral distribution of multinationals in Poland during the 1990s in order to investigate whether multinational firms concentrate in 
particular regions (i.e. border regions) and/or sectors, whether these location patterns have changed over time and whether multinationals follow the same spatial distribution of domestic ones. These questions draw on the theoretical and empirical findings according to which the generation of backward and forward linkages is more likely in geographically concentrated industries (Holmes, 1995; Hansen, 1993).

In order to give a clear answer to our research questions, we have computed synthetic measures of the spatial distribution of FDI at sector and region levels. We have chosen as basic unit of analysis the (cumulated) number of firms, indicated by $n^{h}$ (with $h=d$ for domestic firms; $m$ for multinationals) in a branch $j$ of manufacturing, expressed as a share, either of the total number of FDI (domestic firms) in region $k$, or of the entire country, at time To explore if multinationals $\left(n^{m}\right)$ and domestic firms $\left(n^{d}\right)$ located in one region concentrate in few manufacturing branches, we take the absolute values of the difference between these shares, summed over all manufacturing branches:

$$
K_{k t}^{h}=\sum_{j} a b s\left(\frac{n_{j k t}^{h}}{\sum_{j} n_{j k t}^{h}}-\frac{\sum_{k} n_{j k t}^{h}}{\sum_{k} \sum_{j} n_{j k t}^{h}}\right)
$$

The Krugman specialisation index (Krugman, 1991) ${ }^{9}$ so computed takes the value zero if a region $k$ has a distribution of FDI (domestic firms) among manufacturing branches identical to the country average, and takes the maximum value of two if the distribution of FDI (domestic firms) in region $k$ is totally different from the country average. Values of this index for each region over the period 1990-1997 are shown in table 1. Figures in bold refer to domestic firms, whose spatial distribution is known only for 1997. The table also reports in the last two rows the regional average in each year and the corresponding value for the services sector.

Looking first at average figures, we note in the manufacturing sector a steady fall in the $K$-index between 1991 to 1997, indicating that regional specialisation, i.e. FDI's concentration in specific sectors within regions, became more homogeneous across the country over time. The opposite happened in the service sector where the steady increase in the specialisation index over the period indicates a progressive concentration of FDI in few regions and branches.

\footnotetext{
${ }^{8}$ The core data on multinationals used in our analysis are derived from PECODB data base, a unique database on FDI which provides detailed firm level information at sector and region level on foreign investments undertaken by Western European firms in Central and Eastern Europe (Alessandrini, 2000). Domestic firms' figures, instead, come from AMADEUS CD-ROM, a pan European financial database provided by Bureau Van Dijk Electronic Publishing S.A. Both type of firms have been classified by regional classification according to the level-3 Nomenclature of Territorial Units for Statistics (NUTS). In addition, firms are classified by 3-digits NACE Rev. 1 code on the basis of their main production.

9 Following the most relevant empirical studies on this topic, "specialisation" refers to the geographical perspective, while "concentration" to a sectoral one. See among others Hallet (2000), Amiti (1998 and 1999).
} 
[Table 1 about here]

Turning to individual regions, we observe that at the beginning of the period, only a small set of regions shows a FDI specialisation completely different from the country's pattern. It includes, apart from the capital region, the old industrial poles of Poznan (Wielkopolskie), Lodz (Lodzkie) and Lubel (Lubelskie). However, while Warsaw seems to have lost its specialisation immediately $\frac{10}{10}$ the other industrial poles maintain it for all the early 1990s, becoming more similar to other regions' specialisation patterns only from 1993 onwards. The other regions which show a specialisation different from the national average were the Western border regions, and particularly the south-western region of Zachodnio Pomorskie, whose $K$-index was very close to the superior bound in 1991-1993 $\frac{11}{1}$. After 1995 , the $K$-index behaved homogeneously in all regions, indicating that most of changes in the location patterns of FDI had occurred in 1993-1995, as shown by the absolute changes of the index. In 1997, only one region, i.e. Podlaskie, differs significantly from the country average in terms of FDI hosted $(K=1.71)$, although the figure is decreasing progressively. This is probably due to the delay with which FDI started to be located in such a peripheral region, located in the Northeastern part of the country, at the Belarus border.

Several interesting conclusions emerge from this static analysis. First of all, FDI in Poland seem to follow an homogeneous pattern of dispersion over time. MNEs were located initially in the old industrial poles (Warsaw included), and then spread off all over the country, following what can be defined an "hub and spoke" pattern (Alessandrini and Contessi, 1999). This pattern implies that, in terms of geographical concentration, FDI location choices have likely been driven by market targets or strategic motivations rather than by the presence of other multinationals. Secondly, proximity to Western Europe does not seem to have been a driving factor in terms of location of FDI, at least in the early phase of transition.

Given these dynamics, the static analysis relative to the simple location of foreign investments supports only in part the idea of agglomeration phenomena among multinationals operating in Poland. More interesting is the fact that the location patterns of multinationals show an important similarity with those of domestic firms, since in 1997 the $K$-indexes are rather convergent. This result indicates, not surprisingly, that regional specific effects may have a role in attracting manufacturing plants in specific branches.

\footnotetext{
${ }^{10}$ Warsaw shows a relative concentration of FDI in services much higher than in manufacturing.

${ }^{11}$ In this case, the Krugman specialisation index has to be interpreted with extreme caution, since it accounts for both positive and negative deviations from the average, i.e. it does not allow to distinguish between specialisation and de-specialisation dynamics in the location patterns of firms. A more in-depth analysis would show that border regions display a specialisation patterns of FDI barely different from the national ones (Altomonte and Resmini, 1999).
} 
The sectoral perspective of the spatial patterns of multinational and domestic firms in Poland has been measured by the following coefficient of variation (Hallet, 2000):

$$
V_{j t}^{h}=\frac{1}{\bar{S}_{j k t}^{h}} \sqrt[2]{\frac{\sum_{k}\left(S_{j k t}^{h}-\bar{S}_{j k t}^{h}\right)^{2}}{N}}
$$

where $\frac{12 .}{1 .}$

$$
S_{j k t}^{h}=\frac{n_{j k t}^{h}}{\sum_{j} n_{j k t}^{h}} / \frac{\sum_{k} n_{j k t}^{h}}{\sum_{k} \sum_{j} n_{j k t}^{h}}
$$

and

$N=$ total number of regions $(N=16)$

$\mathrm{T}=1990, \ldots, 1997$ for multinationals $\left(n^{m}\right)$ and only 1997 for domestic firms $\left(n^{d}\right)$

$V_{j t}^{h}$ is a measure of concentration and captures the spatial dispersion of firms. Table 2 presents the results by branches and over time.

[Table 2 about here]

Two interesting patterns emerge from our findings. First of all, in 1990 multinationals were spatially concentrated in all sectors but apparels (NACE Code 18). Secondly, the coefficients of variation follow for most branches a decreasing trend, confirming the hypothesis that multinationals were more spatially concentrated at the beginning of the transition. This process of de-concentration has been particularly strong for furniture (36), metal products (28), electrical machinery and apparatus (31). In 1997, concentration of FDI was particularly higher in six sectors, i.e. tobacco (16), printing products (22), metals (27), computers and automatic data processing machines (30), medical and precision instruments (33) and other transport equipment (35). Finally, at the end of the period, the spatial distribution of multinationals is consistent with that of domestic firms.

The convergence of the patterns of location of the two groups of firms indicates the existence of a relationship between them; the statistical analysis shows the existence of a significant positive correlation between the presence of multinational firms in a given sector/region and their domestic counterparts (Table 3). The theoretical model previously

\footnotetext{
${ }^{12}$ The interpretation of $S_{j k t}^{h}$ index is straightforward: When $S_{j k t}^{h}=1$ sector $j$ share of multinationals (domestic firms) in region $k$ matches that of the average of all the regions in Poland. Instead, if $S_{j k t}^{h}>1\left(S_{j k t}^{h}<1\right)$ sector $j$ share of multinationals (domestic firms) in region $k$ is greater (less) than the average of all the regions in the country; therefore, multinationals (domestic firms) in region $k$ is more (less) concentrated in sector $j$ than the average of all the regions. For a more in depth-discussion of the properties of this index, see Altomonte and
} 
sketched explains such agglomeration patterns through the creation of backward and forward linkages generated by the entry of multinationals, which significantly affects the performance of domestic firms, leading eventually to an increase in their number (catalyst effect). It is therefore worth using econometric techniques to check whether the forces responsible for such agglomeration patterns are actually those identified by the economic theory.

[Table 3 about here]

\section{The econometric model}

In principle, many different factors can be responsible for the generation of agglomeration effects, deriving from both NEG theories and the traditional location determinants identified by neo-classic theories. In particular, in order to disentangle "pure" NEG effects, we have to control for region-specific endowments and industry-specific dynamics (Brülhart, 1998, p. 796). Failing to do so would lead us to a critical identification problem: if multinationals gravitate towards more productive industries or regions, then the possible correlation between the presence of multinationals and the performance of domestically-owned firms will not necessarily be dependent on the positive impact of foreign investments (Aitken and Harrison, 1999, p. 606). The theoretical approach previously described rests however on an intra-industry mechanism of backward and forward linkages that explicitly models these firm interactions through industry specific effects (consumption versus intermediate goods); such a structure should allow us to overcome, at least in principle, the identification problem. Thus, the model to estimate has to be based on the following general structure:

$$
\begin{aligned}
& \text { (A) } \Pi_{j k t}^{i d}=\alpha_{0}+\alpha_{1} n_{j k t}^{i m}+\alpha_{2} n_{j k t}^{m}+\alpha_{3} n_{j k}^{d} * n_{j k t}^{i m}+\alpha_{4} \mathrm{I}_{j t}^{i}+\varepsilon_{j k t} \\
& \text { (B) } \Pi_{j k t}^{d}=\alpha_{0}+\alpha_{1} n_{j k t}^{m}+\alpha_{2} n_{j k t}^{i m}+\alpha_{3} n_{j k}^{i d} * n_{j k t}^{m}+\alpha_{4} \mathrm{I}_{j t}^{i}+\varepsilon_{j k t}
\end{aligned}
$$

where the superscripts indicate the type of firm (domestic $d$ vs. multinational $m$ ) and industry (intermediate $i$ vs. consumption, where no indication appears), while the subscripts indicate the $j^{\text {th }}$ sector of the $k$ region in year $t$. In order to measure backward and forward linkages, each sector $j$ is considered in its two components of consumption and intermediate goods production (see Annex 2), allowing us to identify backward and forward linkages accruing on the upstream (equation A) vs. downstream (equation B) domestic firms.

The dependent variable is the performance $\left(\Pi_{j k t}\right)$ of upstream (downstream) domestic firms, which is, according to the theory, affected by multinationals through three channels:

Resmini (1999). 
i) a direct product competition effect generated by the presence of multinationals (measured by $n$ ) operating in the same upstream (downstream) industry of domestic firms;

ii) a backward (forward) linkage effect created by the presence of multinationals operating in the downstream (upstream) industry;

iii) the combination of a backward and forward linkage effect obtained via the interaction of multinationals in the upstream (downstream) industry and domestic firms in the downstream (upstream) industry.

On the right hand side of the equations, therefore, the first variable indicates product competition effects. The second variable measures backward (forward) linkages, relating multinationals and domestic firms operating in the two different industries: since this effect is a function of the degree with which multinationals use local intermediates, we have to control for that in the regression through the term $I_{j t}^{i}$. Finally, the third variable of the model captures the effect of the interaction between multinationals and domestic firms in the relevant industries.

Apart from the "catalyst" outcome, our theoretical hypotheses suggest also that, once allowing for the entry of multinationals also in the upstream industry, backward and forward linkages between multinationals and domestic firms may be weakened by the presence of self-agglomeration effects among multinationals (see fig. 1c and 1d). In order to estimate the importance of these effects, we have thus to consider also the following model:

$$
\begin{aligned}
& \text { (C) } n_{j k t}^{i m}=\alpha_{0}+\alpha_{1} n_{j k t}^{m}+\alpha_{2} n_{j k}^{i d}+\alpha_{3} n_{j k}^{d}+\alpha_{4} \mathrm{I}_{j t}^{i}+\varepsilon_{j k t} \\
& \text { (D) } n_{j k t}^{m}=\alpha_{0}+\alpha_{1} n_{j k t}^{i m}+\alpha_{2} n_{j k}^{d}+\alpha_{3} n_{j k}^{i d}+\alpha_{4} \mathrm{I}_{j t}^{i}+\varepsilon_{j k t}
\end{aligned}
$$

where symbols have the usual meaning.

According to these equations the presence of upstream (downstream) multinationals in sector $j$, region $k$ at time $t$, may be affected by:

i) a self-agglomeration process among multinationals, picked by the first variable on the right hand side of the equations (Wheeler and Mody, 1992);

ii) a product competition effect generated by the presence of domestic firms operating at the same stage of production, measured by the second explanatory variable of both equations; iii) a backward (forward) linkage created by the presence of domestic firms operating in the downstream (upstream) industry, which is in turn a function of the degree of intensity in the use of intermediates (last two variables of the equations).

We recall that, in order to end up with a catalyst effect, self agglomeration processes among multinationals should not fully offset backward and forward linkages.

Integrating both specifications with a model design which appropriately controls for region specific endowments, as well as industry specific characteristics, as previously mentioned, should then lead to a correct identification of "pure" NEG effects operating within 
the samples of firms (domestic vs foreign firms) in each type of industry (consumption goods vs intermediates in each sector $j$ ). For this reason, we control in both models for a full set of $k$ region-specific dummy variables $\left(\phi_{k}\right)$ and of $j$ sector specific dummy variables, $\vartheta_{j}$. Moreover, in order to capture possible common aggregate shocks over the period considered, or some other unobserved time varying factors, we also include fixed time effects, $\tau_{t}$. This implies that the error term of the model, $\varepsilon_{j k t}$, can be written as follows:

$$
\text { (E) } \varepsilon_{j k t}=\phi_{k}+\vartheta_{j}+\tau_{t}+\eta_{j k t}
$$

where $\eta_{j k t}$ is the standard i.i.d. residual.

\subsection{Definition of variables and econometric issues}

The combination of the regional and sector dimension yields a panel data specification of sectors $j$ and regions $k$ over time $t$ (1995-1998). We have aggregated firm-level observations for both European multinationals and domestic firms over the defined 16 NUTS-III Polish regions (see Annex 1) for ten different manufacturing sectors: Food, Textiles, Chemicals, Metal Products, Motor vehicles, Domestic Appliances, Leather, Wood and Furniture, Paper and printing products. The distinction between intermediates and consumption goods industry is undertaken, in the absence of input-output tables for Poland, through the assignment of each firm (domestic or multinational) to the $i$ - or $c$-industry according to the classification reported in Annex 2 13.

The dependent variables proxying domestic firms' performance in the upstream and downstream industries (equations A and B) are the aggregated (over firm data) level of sales of domestic firms in each industry in sector $j$ and region $k$ in year $t$. We use as a dependent variable aggregated, and not per capita, sale figures since we are interested in exploring the impact of the presence of multinationals on the overall performance of the local industry, in terms of its possible expansion (and hence the birth of catalyst effects) 14 .

In order to avoid problems of simultaneity between the presence of multinationals and the performance of domestic firms, we have lagged one period all the observations related to

\footnotetext{
${ }^{13}$ The classification is derived from the NACE-CLIO classification and coding of branches and products of the European Union, at the basis of the construction of input-output tables.

${ }^{14}$ An entry of a multinational firm inducing, via forward linkages, an entry of a certain number of domestic firms, can be such to generate a decrease (and not an increase) of per capita domestic firms' sales. On the contrary, the relationship between aggregated domestic firms' sales and the number of multinationals operating in the industry can go only in an univocal direction according to the kind of effect generated.
} 
MNEs, measuring their presence through the concentration of multinationals, calculated for the $i$ - and $c$-type industries, operating in sector $j$ in region $k$ over time ${ }^{15}$.

The interaction term of domestic and multinational firms is calculated as the product of the share of upstream (downstream) multinationals in a given sector/region, lagged one period, times the number of downstream (upstream) domestic firms operating in the same sector/region, when modelling $i$ - and $c$-type domestic firms, respectively. The intensity in the use of locally produced intermediates has been proxied by the international trade orientation of each sector, measured as the share of imports (exports) of the $i$-industry over the total import and export flows of the sector $\frac{16}{16}$. As a result, taking the natural logarithm of the total sales level of domestic firms, the baseline model to be estimated takes the following form:

$$
\begin{gathered}
s_{j k t}^{i d}=\alpha_{0}+\alpha_{1} q_{j k t-1}^{i m}+\alpha_{2} q_{j k t-1}^{m}+\alpha_{3} n_{j k}^{d} * q_{j k t-1}^{i m}+\alpha_{4} I M P_{j t}^{i}+\alpha_{5} \phi_{k}+\alpha_{6} \vartheta_{j}+\alpha_{7} \tau_{t}+\eta_{j k t} \\
s_{j k t}^{d}=\alpha_{0}+\alpha_{1} q_{j k t-1}^{m}+\alpha_{2} q_{j k t-1}^{i m}+\alpha_{3} n_{j k}^{i d} * q_{j k t-1}^{m}+\alpha_{4} E X P_{j t}^{i}+\alpha_{5} \phi_{k}+\alpha_{6} \vartheta_{j}+\alpha_{7} \tau_{t}+\eta_{j k t}
\end{gathered}
$$

Concerning equations $\mathrm{C}$ and $\mathrm{D}$, we estimate possible self agglomeration effects considering the (cumulated) number of multinationals and domestic firms in region $k$, sector $j$ and year $t$, operating in upstream (C) and downstream (D) industry. As before, explanatory variables referring to multinationals have been lagged one period to avoid simultaneity problems. Therefore, the equations to be estimated are specified as follows:

$$
\begin{aligned}
& n_{j k t}^{i m}=\alpha_{0}+\alpha_{1} n_{j k t-1}^{m}+\alpha_{2} n_{j k}^{i d}+\alpha_{3} n_{j k}^{d}+\alpha_{4} \mathrm{I} M P_{j t}^{i}+\alpha_{5} \phi_{k t}+\alpha_{6} \vartheta_{j}+\alpha_{7} \tau_{t}+\eta_{j k t} \\
& n_{j k t}^{m}=\alpha_{0}+\alpha_{1} n_{j k t-1}^{i m}+\alpha_{2} n_{j k}^{d}+\alpha_{3} n_{j k}^{i d}+\alpha_{4} E X P_{j t}^{i}+\alpha_{5} \phi_{k}+\alpha_{6} \vartheta_{j}+\alpha_{7} \tau_{t}+\eta_{j k t}
\end{aligned}
$$

We use the cumulated number of multinationals rather than shares since in this model specification we are interested in capturing "pure" location patterns of the same multinationals, regardless of their concentration dynamics in each sector/region. Given the specification of Models 1A to 1D, standard fixed-effects panel estimation techniques have been employed for all models.

${ }^{15}$ We use the following indexes of absolute concentration $q_{j k t}^{m}=\frac{n_{j k t}^{m}}{\sum_{j}\left(n_{j k t}^{m}+n_{j k t}^{i m}\right)}$ for the $c$-industry and $q_{j k t}^{i m}=\frac{n_{j k t}^{i m}}{\sum_{j}\left(n_{j k t}^{m}+n_{j k t}^{i m}\right)}$ for the $i$-industry.

${ }^{16}$ Data refer to the total trade flows of Poland with the EU, as derived from the COMEXT database. 


\subsection{Estimation Results}

The first two columns of Table 4 show the results of the econometric estimation for equations $1 \mathrm{~A}$ and $1 \mathrm{~B}$.

The combined analysis of the two equations reveals that multinationals can act as a catalyst for industrial development. An increase in the concentration of multinationals in the consumption goods industry has significant positive effects (backward linkage) on the level of sales of domestic firms in the upstream industry (column 1A). The reverse (evidence of a forward linkage) is true for the performance of domestic firms in the downstream industry (column 1B). The quantitative effect of these linkages appears to be strong in both

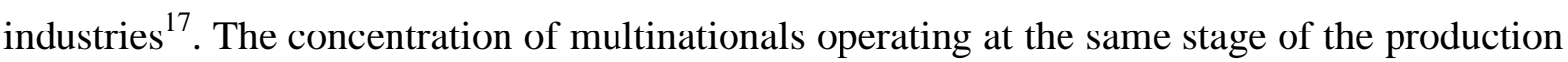
process of domestic firms seems not to affect significantly the performance of domestic firms, indicating that potential product competition effects do not weaken eventual backward and forward linkages. Concerning the interactions between domestic firms and multinationals, a positive relationship is recorded in both industries, although statistically significant only in the $c$-type industry. Finally, the fact that the coefficients of the export and import orientation of the intermediate sector are not statistically significant suggests that backward and forward linkages are not affected by the availability of locally produced intermediates. However, trade orientation is only an indirect measure of the underlying production structure; consequently, this last result has to be interpreted with extreme caution.

Interpreting the econometric outcome in light of the theoretical model behind this econometric exercise, we find therefore general support for the idea that the entry of multinationals can act, via backward and forward linkages, as an incubator of industrial development. In particular, we have shown that downstream domestic firms benefit from forward linkages of upstream multinationals and from forward linkages deriving from upstream domestic firms, which in turn take advantage of the backward linkages accruing from the presence of multinationals in the downstream industry. However, since we do not find a significant evidence of backward linkages from downstream to upstream domestic firms, we can not support the idea of an agglomeration pattern ignited by multinationals and then self-sustaining only among domestic firms, at least within this model design. In other words, according to our theoretical framework, the continuous entry of multinationals over time is a necessary condition for this economy to generate positive growth levels $\frac{18}{1}$.

\footnotetext{
${ }^{17}$ These coefficients are relative growth rates, since domestic firm sales are in the log form.

${ }^{18}$ Theoretically, this can be explained by the fact that, since in our framework downstream domestic firms are not forced to buy intermediates from upstream domestic firms (while Markusen and Venables (1999) model the intermediate sector as non-tradable), the possibility of exploiting upstream multinationals or importing the intermediate goods loosen their links with upstream domestic firms.
} 
Finally, we find no evidence for time effects, while region and sector heterogeneity affect domestic firms' performance, as expected.

[Table 4 about here]

Following our theoretical framework, in order to evaluate the magnitude of the relationships previously discussed, we also need to consider the presence of potential selfagglomeration effects among multinationals. In this case, we are interested in understanding whether multinationals' location processes are driven by the presence of other, already established, foreign firms, rather than by domestic firms $\underline{19}$. In fact, if self-agglomeration phenomena accrue on multinationals and depend negatively from the presence of domestic firms, a further entry of multinationals can offset the results previously discussed, eventually leading to the creation of "enclave" economies within the host country (Rodriguez-Clare, 1996; Hardy, 1998).

Table 5 provides the estimation results for equations $1 \mathrm{C}$ and $1 \mathrm{D}$ in its first two columns. Multinationals evaluate significantly and positively self-agglomeration benefits, but these accrue not only within multinationals, but also between multinationals and domestic firms, in line with the empirical evidence shown in section three. Again, sector and region heterogeneity exert a significant effect on the location decision processes of multinationals.

[Table 5 about here]

\subsection{Robustness issues and sensitivity analysis}

In order to check the robustness of our findings, we have tested alternative specifications of our general equations. We introduce two types of differences: first of all, we adopt different proxies for our explanatory variables; secondly, we impose some restrictions on the sample.

Concerning the first model, we consider a different measure of the presence of multinationals at sector and region level. In particular, we re-estimate equations $\mathrm{A}$ and $\mathrm{B}$ substituting the share of multinationals in each industry, sector and regions with the sectoral specification of the previously defined Krugman index, lagged one period. We therefore use a measure of relative and not absolute concentration. The results are shown in columns $2 \mathrm{~A}$ and 2B of table 4. Coefficient magnitudes and patterns of significance are in line with those in the corresponding first two columns of table 4. In addition, the results clearly indicate the presence of a significant direct product competition effect in the $c$-industry, of a "pure" spillover effect in the $i$-industry, and a positive backward linkage effect accruing to upstream

\footnotetext{
${ }^{19}$ Evidence for self-agglomeration effects among multinationals is provided by Wheeler and Mody (1992).
} 
domestic firms from the interaction of upstream multinationals and downstream domestic firms and vice-versa. Although these results are perfectly consistent with our theoretical hypotheses, even strengthening the significance of our findings (we have here evidence of a catalyst outcome), it should be mentioned that the previously discussed ambiguity that characterises the interpretation of the Krugman index is not overcome by the econometric analysis. However, the fact that absolute and relative concentration measures exert the same impact on the performance of domestic firms reassuringly indicates that we might be considering specialisation and not de-specialisation patterns in both cases.

As far as the second model is concerned, we consider as a robustness test the explicit inclusion of regional characteristics. According to the literature on FDI determinants, multinationals consider in their decision processes the following location variables 20 .

- the gross domestic product of each region $k$ over time, denoted as $\mathbf{g d p}_{\mathbf{k t}}$ and derived by Eurostat, as a proxy for the absolute size of the local market ${ }^{21}$ (Wheeler and Mody, 1992);

- the distance of the quickest road link between the capital city of each region and Warsaw $\left(\operatorname{dist} \mathbf{W A}_{\mathbf{k}}\right.$ ) and a specific dummy for Western regions (border), in order to test whether it exists a positive relationship between agglomeration effects and the proximity to the region with which the area is establishing an integration process (Hanson, 1998).

Columns 2C and 2D of table 5 show the results of this further estimation. Again, the results are very similar to the corresponding columns 1C and 1D. Regional characteristic variables have the expected sign and are statistically significant in the consumption good subsample, while multinationals operating in the intermediate industry positively react to an increase in the GDP level, indicating that they might prefer locations with better infrastructures. The lack of significance of the distance variable in this case might suggest that upstream multinationals serve prevalently local customers (both foreign and domestic).

In terms of sensitivity analysis, we re-estimate equations $1 \mathrm{~A}$ and $1 \mathrm{~B}$ imposing two restrictions on the sample. So far, we have in fact assumed that backward and forward linkages among multinationals and domestic firms accrue equally in all sectors and regions. This approach is somewhat restrictive. Some sectors produce goods that are intensive in some immobile inputs, while some regions, may have a concentration of firms, in absolute terms, structurally higher than other locations, increasing for that reason the probability to generate backward and forward linkages. In order to control for potential sample biases that could generate spurious results, we alternatively drop from the sample the Paper and printing sector,

\footnotetext{
${ }^{20} \mathrm{We}$ recall however that the focus of this paper is not an analysis of FDI determinants. Rather, we are interested in discovering whether multinationals, given their location, generate backward and forward linkages with domestic firms.

${ }^{21}$ At the beginning, we included also two different measures of the level of infrastructures. We dropped both of them since they show a very strong correlation with the level of GDP.
} 
which is relatively intensive in immobile resources (Hanson, 1998), and the observations relative to the capital region 22 .

Table 6 shows the results for equations $1 \mathrm{~A}$ and 1B. Again the results are quite similar to those in the corresponding columns of table 4.

[Table 6 about here]

\section{Conclusions and policy implications}

This paper studies the impact of multinationals on the industrial structure of the host country. We focus on the generation of backward and forward linkages distinguishing effects accruing between multinationals and domestic firms from those involving only foreign-owned enterprises. The particular case we consider is Poland, one of the most advanced accession country, with a conspicuous inflow of FDI, coming mainly from Western Europe.

The results obtained seem consistent with the peculiar experience of this country. It has been already stated by the theory (Blanchard, 1997) and also by the empirical evidence (Alessandrini, 2000), that the early entry of multinationals in both stages of the production processes is likely to have disrupted historic ties between domestic firms operating along the value-added chain (the so-called "creative disruption"), forcing the same firms to go through costly restructuring, and only later stimulating economic growth, as witnessed by the ushaped pattern of industrial output in transition countries over time. Our results fit nicely within this framework, since we find positive backward and forward linkages accruing from multinationals to domestic firms, and hence stimulating growth once multinationals are established, but not a significant interaction between upstream and downstream domestic firm, a signal that historic ties have been disrupted and (eventually) still need to be reconstructed. Another interesting fact emerging from our analysis is that multinationals seem to condition their location also on the presence of domestic firms.

These findings have some clear policy implications: the presence of FDI maximises its positive effects for the host country when multinationals can capitalise on a pre-existing structure of domestic firms, of which they enhance the performance and hence contribute, as "incubators", to the creation of a sound local industrial structure. Once the presence of multinational firms is established, this becomes however a necessary condition for industrial development, since such a presence is not sufficient to generate a self-sustaining pattern of growth within domestic firms, given the fact that these firms do not seem to significantly interact among themselves. Hence, the need of policies aimed at either sustaining the entry of

\footnotetext{
${ }^{22}$ We have not enough degrees of freedom to either consider simultaneously these restrictions or the possibility to drop other regions or sector from the sample.
} 
multinationals over time or at (re)building stronger industrial ties among domestic firms, which in turn might stimulate the location of multinationals and generate the catalyst effects postulated by the theory. 
Fig. 1. Entry of multinationals and catalyst effect on domestic firms

$$
\begin{aligned}
& \text { Figure 1a (Markusen and Venables, 1999): } \\
& \begin{array}{l}
\uparrow n_{c}^{m} \Rightarrow \uparrow n_{i}^{d} \Rightarrow \uparrow n_{c}^{d} \Rightarrow \uparrow n_{i}^{d} \Rightarrow \\
\text { (backward linkage) } \quad \text { (forward linkage) } \quad \text { (catalyst effect) } \\
\Rightarrow \downarrow n_{c}^{d}
\end{array}
\end{aligned}
$$

(product competition effect)

Figure $1 b$

$\uparrow n_{i}^{m} \Rightarrow \uparrow n_{c}^{d} \Rightarrow \uparrow n_{i}^{d} \Rightarrow \uparrow n_{c}^{d} \Rightarrow \ldots \ldots$

(forward linkage) (backward linkage) (catalyst effect)

$$
\Rightarrow \downarrow n_{i}^{d}
$$

(product competition effect)

Figure 1c

$\uparrow n_{c}^{m} \Rightarrow \uparrow n_{i}^{m} \Rightarrow \uparrow n_{c}^{m} \Rightarrow \uparrow n_{i}^{m} \Rightarrow \ldots \ldots$

(backward linkage) (forward linkage) (self-agglomeration of MNEs)

(crowding out of domestic firms)

$$
\Rightarrow \downarrow n_{c}^{d}
$$

(product competition effect)

Figure 1d

$\uparrow n_{i}^{m} \Rightarrow \uparrow n_{c}^{m} \Rightarrow \uparrow n_{i}^{m} \Rightarrow \uparrow n_{c}^{m} \Rightarrow \ldots \ldots$

(forward linkage) (backward linkage) (self-agglomeration of MNEs)

(crowding out of domestic firms)

$$
\Rightarrow \downarrow n_{i}^{d}
$$


Table 1. Krugman specialisation index $\left(K_{k t}^{h}\right)$ by region and year

\begin{tabular}{|c|c|c|c|c|c|c|c|c|c|c|c|c|}
\hline & 1990 & 1991 & 1992 & 1993 & 1994 & 1995 & 1996 & 1997 & D & $1992 / 1990$ & $1995 / 1993$ & $1996 / 1997$ \\
\hline Dolnoslaskie* & n.a. & 1.57 & 1.27 & 0.97 & 0.82 & 0.59 & 0.55 & 0.55 & 0.35 & n.a. & -0.38 & 0.00 \\
\hline Kujawsko-Pomorskie & 0.92 & 1.06 & 0.86 & 0.87 & 0.77 & 0.70 & 0.67 & 0.66 & 0.56 & -0.06 & -0.16 & -0.02 \\
\hline Lubelskie ${ }^{\star \star}$ & 1.69 & 1.69 & 1.78 & 1.17 & 0.98 & 0.97 & 0.93 & 0.92 & 0.96 & 0.08 & -0.20 & -0.01 \\
\hline Lubuskie* & n.a. & 1.73 & 1.55 & 1.34 & 1.11 & 1.15 & 1.00 & 1.06 & 1.01 & n.a. & -0.19 & 0.07 \\
\hline Lodzskie $^{\star *}$ & 1.69 & 1.25 & 1.03 & 0.84 & 0.79 & 0.70 & 0.69 & 0.67 & 0.58 & -0.66 & -0.14 & -0.01 \\
\hline Malopolskie & n.a. & 1.76 & 1.35 & 1.39 & 1.08 & 0.80 & 0.81 & 0.81 & 0.57 & n.a. & -0.59 & 0.01 \\
\hline Mazowieckie ${ }^{* \star *}$ & 1.69 & 0.64 & 0.54 & 0.58 & 0.48 & 0.46 & 0.45 & 0.45 & 0.44 & -1.15 & -0.12 & 0.00 \\
\hline Opolskie & n.a. & n.a. & 1.48 & 1.27 & 1.22 & 1.18 & 1.19 & 1.18 & 0.99 & n.a. & -0.10 & -0.01 \\
\hline Podkarpackie & n.a. & n.a. & 1.38 & 1.30 & 1.10 & 1.06 & 0.90 & 0.90 & 0.59 & n.a. & -0.24 & 0.00 \\
\hline Podlaskie & n.a. & n.a. & n.a. & n.a. & 1.88 & 1.78 & 1.72 & 1.71 & 0.87 & n.a. & n.a. & -0.01 \\
\hline Pomorskie $^{* *}$ & 1.23 & 1.61 & 1.04 & 0.71 & 0.65 & 0.66 & 0.68 & 0.69 & 0.98 & -0.19 & -0.05 & 0.01 \\
\hline Slaskie** & n.a. & 1.76 & 1.36 & 0.91 & 0.87 & 0.80 & 0.63 & 0.65 & 0.72 & n.a. & -0.10 & 0.02 \\
\hline Swietokrzyskie & n.a. & n.a. & 1.48 & 1.53 & 1.50 & 1.21 & 1.10 & 1.11 & 1.19 & n.a. & -0.32 & 0.00 \\
\hline Warminsko-Mazurskie & n.a. & 1.76 & 1.25 & 1.21 & 1.05 & 1.02 & 1.06 & 1.05 & 0.92 & n.a. & -0.19 & -0.01 \\
\hline Wielkopolskie ${ }^{\star *}$ & 1.69 & 1.25 & 1.05 & 0.49 & 0.44 & 0.37 & 0.34 & 0.34 & 0.56 & -0.64 & -0.12 & -0.01 \\
\hline Zachodnio-Pomorskie* & 1.54 & 1.80 & 1.85 & 1.75 & 1.53 & 0.87 & 0.78 & 0.79 & 0.76 & 0.31 & -0.88 & 0.01 \\
\hline Average & 1.49 & 1.49 & 1.28 & 1.09 & 1.02 & 0.89 & 0.84 & 0.85 & 0.75 & -0.21 & -0.19 & 0.00 \\
\hline Service sector & 1.06 & 1.13 & 1.15 & 1.42 & 1.41 & 1.42 & 1.44 & 1.44 & 0.88 & & & \\
\hline
\end{tabular}

*Regions bordering with Western Europe. **Industrial poles. ***Capital Region.

Figures in bold refer to domestic firms in 1997.

Table 2. Coefficients of variation $\left(V_{j t}^{h}\right)$ by sector and year

\begin{tabular}{llllllllll}
\hline & $\mathbf{1 9 9 0}$ & $\mathbf{1 9 9 1}$ & $\mathbf{1 9 9 2}$ & $\mathbf{1 9 9 3}$ & $\mathbf{1 9 9 4}$ & $\mathbf{1 9 9 5}$ & $\mathbf{1 9 9 6}$ & $\mathbf{1 9 9 7}$ & $\mathbf{D}$ \\
\hline 15 & & & & & & & & \\
16 & 1.43 & 1.42 & 0.95 & 0.84 & 0.80 & 0.44 & 0.44 & 0.46 & $\mathbf{0 . 4 9}$ \\
17 & & 2.92 & 3.63 & 2.79 & 3.13 & 2.52 & 1.99 & 2.00 & $\mathbf{3 . 8 7}$ \\
18 & 0.92 & 1.90 & 2.18 & 1.16 & 1.05 & 0.98 & 1.01 & 1.00 & $\mathbf{1 . 7 3}$ \\
19 & 1.79 & 2.92 & 3.63 & 2.53 & 2.81 & 2.35 & 1.79 & 1.80 & $\mathbf{1 . 4 6}$ \\
20 & 1.79 & 1.70 & 1.96 & 1.98 & 2.14 & 1.89 & 1.62 & 1.63 & $\mathbf{1 . 1 2}$ \\
21 & & & 1.71 & 1.92 & 1.74 & 1.61 & 1.42 & 1.43 & $\mathbf{1 . 3 0}$ \\
22 & & 2.92 & 3.63 & 2.52 & 2.18 & 2.30 & 2.12 & 2.12 & $\mathbf{2 . 2 2}$ \\
24 & 1.79 & 2.18 & 1.77 & 1.30 & 1.40 & 1.23 & 0.93 & 0.95 & $\mathbf{0 . 7 2}$ \\
25 & 1.31 & 1.70 & 1.84 & 1.27 & 1.24 & 1.32 & 0.99 & 0.97 & $\mathbf{0 . 9 7}$ \\
26 & & 2.02 & 1.92 & 1.65 & 1.14 & 1.14 & 0.89 & 0.90 & $\mathbf{0 . 9 2}$ \\
27 & & & 2.93 & 2.23 & 2.12 & 2.12 & 2.12 & 2.12 & $\mathbf{1 . 4 0}$ \\
28 & & 2.92 & 2.33 & 1.55 & 1.69 & 1.43 & 1.25 & 1.25 & $\mathbf{0 . 6 3}$ \\
29 & 1.79 & 1.34 & 1.47 & 1.39 & 2.10 & 1.69 & 1.35 & 1.30 & $\mathbf{0 . 6 9}$ \\
30 & & & na & na & 3.87 & 3.87 & 2.99 & 2.99 & $\mathbf{2 . 6 5}$ \\
31 & & 2.43 & 1.98 & 1.46 & 1.25 & 1.23 & 1.24 & 1.25 & $\mathbf{1 . 0 5}$ \\
32 & & 2.53 & 2.01 & 1.75 & 1.76 & 1.75 & 1.75 & 1.74 & $\mathbf{1 . 9 3}$ \\
33 & & 2.35 & 2.74 & 2.63 & 2.80 & 2.78 & 2.22 & 2.23 & $\mathbf{2 . 7 2}$ \\
34 & 1.79 & 2.64 & 2.66 & 1.77 & 1.62 & 1.48 & 1.49 & 1.50 & $\mathbf{1 . 6 4}$ \\
35 & 1.79 & 2.92 & 3.63 & 3.63 & 2.71 & 2.73 & 2.16 & 2.16 & $\mathbf{1 . 1 1}$ \\
36 & & 2.92 & 2.25 & 1.81 & 1.56 & 1.46 & 1.13 & 1.10 & $\mathbf{1 . 1 8}$ \\
\hline
\end{tabular}

Figures in bold refer to domestic firms in 1997. Nace Rev. 1 codes in the left hand column are explained in the Annex. 
Tab. 3 - multinationals vs domestic firms' patterns of location $(t=1997)$

\begin{tabular}{lll}
\hline & $K_{k t}^{d}$ & $V_{j t}^{d}$ \\
\hline$K_{k t}^{m}$ & $0.798^{*}$ & \\
$V_{j t}^{m}$ & $(\mathrm{~N}=16)$ & $0.690^{*}$ \\
& & $(\mathrm{~N}=21)$ \\
\hline
\end{tabular}

Spearman's rho coefficient of correlation;

*correlation is significant at 0.01 level.

Table 4: Testing for catalyst effects among multinational and domestic firms

\begin{tabular}{|c|c|c|c|c|}
\hline Variables $^{\text {a }}$ & MODEL 1A & MODEL 1B & MODEL 2A & MODEL 2B \\
\hline$s^{\text {id }}$ & DepVar & & DepVar & \\
\hline$s^{d}$ & & DepVar & & DepVar \\
\hline $\mathrm{q}^{\mathrm{m}}$ & $\begin{array}{c}4.24 * * * \\
(1.18)\end{array}$ & $\begin{array}{l}-.450 \\
(.895)\end{array}$ & & \\
\hline $\mathrm{q}^{\mathrm{im}}$ & $\begin{array}{c}1.04 \\
(1.25) \\
\end{array}$ & $\begin{array}{c}2.49 * * * \\
(.713)\end{array}$ & & \\
\hline $\mathrm{K}^{\mathrm{m}}$ & & & $\begin{array}{c}3.53 * * \\
(1.50)\end{array}$ & $\begin{array}{c}-2.45 * * \\
(1.21)\end{array}$ \\
\hline $\mathrm{K}^{\mathrm{im}}$ & & & $\begin{array}{c}4.52 * * * \\
(1.44)\end{array}$ & $\begin{array}{c}3.86 * * * \\
(.864)\end{array}$ \\
\hline $\mathrm{n}^{\mathrm{id}} * \mathrm{q}^{\mathrm{m}}$ & & $\begin{array}{l}.014 * * \\
(.006)\end{array}$ & & $\begin{array}{l}.010^{*} \\
(.006)\end{array}$ \\
\hline $\mathrm{n}^{\mathrm{d}} * \mathrm{q}^{\mathrm{im}}$ & $\begin{array}{c}.010 \\
(.005) \\
\end{array}$ & & $\begin{array}{l}.011 * * \\
.005)\end{array}$ & \\
\hline $\mathrm{EXP}^{\mathrm{i}}$ & & $\begin{array}{l}-.129 \\
(3.18)\end{array}$ & & $\begin{array}{c}302 \\
(3.12)\end{array}$ \\
\hline IMP $^{i}$ & $\begin{array}{c}4.08 \\
(3.80)\end{array}$ & & $\begin{array}{c}5.18 \\
(3.85)\end{array}$ & \\
\hline Regional dummies $^{b}$ & $5.05 * * *$ & $3.76^{* * *}$ & $5.54 * * *$ & $3.89 * * *$ \\
\hline Sector dummies $^{b}$ & $21.05 * * *$ & $7.01 * * *$ & $18.28 * * *$ & $11.64 * * *$ \\
\hline Time dummies $^{b}$ & .22 & .03 & .27 & .01 \\
\hline Const & $\begin{array}{c}5.52 * * * \\
(1.85)\end{array}$ & $\begin{array}{c}12.02 * * * \\
(.687) \\
\end{array}$ & $\begin{array}{c}5.75 * * * \\
(1.88)\end{array}$ & $\begin{array}{c}12.05 * * * \\
(.649) \\
\end{array}$ \\
\hline n. obs. & 291 & 303 & 291 & 303 \\
\hline R. sq. (adj.) & .45 & .39 & .44 & .41 \\
\hline F test & $8.78 * * *$ & $7.41 * * *$ & $8.64 * * *$ & $8.01 * * *$ \\
\hline
\end{tabular}

Standard errors in parenthesis.

${ }^{a}$ All variables related to multinationals (m) are lagged one period.

${ }^{b}$ The Table reports the Wald test of joint significance of coefficients 
Table 5: Testing for self-agglomeration effects among multinationals

\begin{tabular}{|c|c|c|c|c|}
\hline Variables $^{\mathbf{a}}$ & MODEL 1C & MODEL 1D & MODEL 2C & MODEL 2D \\
\hline $\mathrm{n}^{\mathrm{im}}$ & Dep. Var & $\begin{array}{c}.254 * * * \\
(.058)\end{array}$ & Dep. Var & $\begin{array}{c}.301 * * * \\
(.061)\end{array}$ \\
\hline $\mathrm{n}^{\mathrm{m}}$ & $\begin{array}{c}.068 * * * \\
(.024)\end{array}$ & Dep. Var & $\begin{array}{c}.063 * * * \\
(.024)\end{array}$ & Dep.Var \\
\hline$n^{\mathrm{d}}$ & $\begin{array}{l}-.081 \\
(.041) \\
\end{array}$ & $\begin{array}{c}.676 * * * \\
(.065)\end{array}$ & $\begin{array}{l}-.034 \\
(.039)\end{array}$ & $\begin{array}{c}.602 * * * \\
(.066)\end{array}$ \\
\hline $\mathrm{n}^{\text {id }}$ & $\begin{array}{c}.147 * * * \\
(.034)\end{array}$ & $\begin{array}{l}-.054 \\
(.058)\end{array}$ & $\begin{array}{c}.148 * * * \\
(.034)\end{array}$ & $\begin{array}{c}-.123 * * \\
(.061)\end{array}$ \\
\hline $\mathrm{EXP}^{\mathrm{i}}$ & & $\begin{array}{c}1.58 \\
(3.73)\end{array}$ & & $\begin{array}{c}1.66 \\
(4.03)\end{array}$ \\
\hline $\mathrm{IMP}^{\mathrm{i}}$ & $\begin{array}{l}-4.32 \\
(2.53) \\
\end{array}$ & & $\begin{array}{l}-4.25 \\
(2.62) \\
\end{array}$ & \\
\hline $\ln (\mathrm{gdp})$ & & & $\begin{array}{c}.679 * * * \\
(.089)\end{array}$ & $\begin{array}{c}.883 * * * \\
(.156)\end{array}$ \\
\hline DistWA & & & $\begin{array}{l}-.001 \\
(.001)\end{array}$ & $\begin{array}{c}-.004 * * * \\
(.001)\end{array}$ \\
\hline Border & & & $\begin{array}{c}.115 \\
(.162)\end{array}$ & $\begin{array}{c}.803 * * * \\
(.282)\end{array}$ \\
\hline Regional dummies $^{b}$ & $8.19 * * *$ & $12.38 * * *$ & & \\
\hline Sector dummies ${ }^{b}$ & $13.20 * * *$ & $5.85 * * *$ & $12.88 * * *$ & $6.32 * * *$ \\
\hline Time dummies ${ }^{b}$ & $2.74 * *$ & 1.76 & .40 & .47 \\
\hline Const & $\begin{array}{c}2.89 * * \\
(1.23) \\
\end{array}$ & $\begin{array}{c}1.57 \\
(.867) \\
\end{array}$ & $\begin{array}{c}-3.18 * * \\
(1.46)\end{array}$ & $\begin{array}{c}-4.00 * * * \\
(1.52) \\
\end{array}$ \\
\hline n. obs. & 576 & 576 & 576 & 576 \\
\hline R. sq. (overall) & .37 & .66 & .33 & .60 \\
\hline $\mathrm{F}$ test & $12.45 * * *$ & $38.52 * * *$ & $16.57 * * *$ & $49.79 * * *$ \\
\hline
\end{tabular}

Standard errors in parenthesis.

${ }^{a}$ When entering in the estimations as independent variables, the cumulated number of MNEs in the upstream (downstream) industry has been lagged one period in order to avoid potential problems of simultaneity.

${ }^{b}$ The Table reports the Wald test of joint significance of coefficients 
Table 6: Sensitivity Analysis

\begin{tabular}{|c|c|c|c|c|}
\hline Variables $^{a}$ & $\begin{array}{c}\text { Model 3A } \\
\text { (Paper Sector) }\end{array}$ & $\begin{array}{c}\text { Model 3B } \\
\text { (Paper Sector) }\end{array}$ & $\begin{array}{c}\text { Model 4A } \\
\text { (Capital Region) }\end{array}$ & $\begin{array}{c}\text { Model 4B } \\
\text { (Capital Region) }\end{array}$ \\
\hline $\mathrm{s}^{\mathrm{id}}$ & DepVar & & DepVar & \\
\hline$s^{d}$ & & DepVar & & DepVar \\
\hline $\mathrm{q}^{\mathrm{m}}$ & $\begin{array}{l}4.08 * * * \\
(1.18)\end{array}$ & $\begin{array}{l}-.534 \\
(.894)\end{array}$ & $\begin{array}{l}3.51 * * * \\
(1.1)\end{array}$ & $\begin{array}{l}-.807 \\
(.890)\end{array}$ \\
\hline $\mathrm{q}^{\mathrm{im}}$ & $\begin{array}{l}1.10 \\
(1.26) \\
\end{array}$ & $\begin{array}{l}2.53 * * * \\
(.705) \\
\end{array}$ & $\begin{array}{l}.680 \\
(1.18) \\
\end{array}$ & $\begin{array}{l}2.41 * * * \\
(.695) \\
\end{array}$ \\
\hline $\mathrm{n}^{\mathrm{id}} * \mathrm{q}^{\mathrm{m}}$ & & $\begin{array}{l}.013 * * \\
(.006)\end{array}$ & & $\begin{array}{l}.014 * * \\
(.006)\end{array}$ \\
\hline $\mathrm{n}^{\mathrm{d} *} \mathrm{q}^{\mathrm{im}}$ & $\begin{array}{l}.010^{*} \\
(.005)\end{array}$ & & $\begin{array}{l}.020 * * \\
(.008)\end{array}$ & \\
\hline $\mathrm{EXP}^{\mathrm{i}}$ & & $\begin{array}{l}-.761 \\
(3.24)\end{array}$ & & $\begin{array}{l}.173 \\
(3.21)\end{array}$ \\
\hline $\mathrm{IMP}^{\mathrm{i}}$ & $\begin{array}{l}4.32 \\
(3.87)\end{array}$ & & $\begin{array}{l}4.05 \\
(3.58)\end{array}$ & \\
\hline Regional dummies $^{b}$ & $4.94 * * *$ & $4.78 * * *$ & $6.76 * * *$ & $4.19 * * *$ \\
\hline Sector dummies ${ }^{b}$ & $23.11 * * *$ & $7.58 * * *$ & $20.14 * * *$ & $8.13 * * *$ \\
\hline Time dummies $^{b}$ & .28 & .11 & .20 & .02 \\
\hline Const & $\begin{array}{l}5.39 * * * \\
(1.88)\end{array}$ & $\begin{array}{l}12.26 \text { *** } \\
(.713)\end{array}$ & $\begin{array}{l}5.59 * * * \\
(1.73)\end{array}$ & $\begin{array}{l}12.05 * * * \\
(.691)\end{array}$ \\
\hline n. obs. & 282 & 270 & 267 & 279 \\
\hline R. sq. (adj.) & .44 & .42 & .48 & .41 \\
\hline F test & $8.61 * * *$ & $7.83 * * *$ & $9.61 * * *$ & $7.65 * * *$ \\
\hline
\end{tabular}

Standard errors in parenthesis.

${ }^{a}$ All variables related to multinationals (m) are lagged one period.

${ }^{b}$ The Table reports the Wald test of joint significance of coefficients

Models 3A and 3B exclude Paper and printing product sector; models 4A and 4B do not consider Warsaw region. 


\section{References}

Aitken, B.J. and Harrison, E. (1999), "Do Domestic Firms Benefit from Direct Foreign Investment? Evidence from Venezuela", American Economic Review, n. 3, pp. 605-618.

Alessandrini, S. (ed.) (2000), The EU Foreign Direct Investment in Central and Eastern Europe, Giuffrè Editore, Milan.

Alessandrini, S. and Contessi, S. (1999), "The regional location of FDI in Central Europe: an empirical analysis in a comparative perspective", working paper, Phare-ACE project P97-8138-R.

Altomonte, C. and Resmini, L. (1999) "The Geography of Transition: Agglomeration vs. Dispersion of Firms' Activity in the Countries of Central and Eastern Europe", paper presented at the 9th EADI General Conference, 22-27 September, Paris.

Amiti, M. (1998), "New Trade Theories and Industrial Location in the EU: a Survey of Evidence", Oxford Review of Economic Policy, vol. 14, n. 2, pp. 45-53.

Amiti, M. (1999), "Specialisation Patterns in Europe", Weltwirtschaftliches Archiv., vol. 135, n. 4, pp. 573-579.

Blanchard, O. (1997), The Economics of Post-Communism Transition, Clarendon Press, Oxford.

Blomstrom, M. and Kokko, A. (1997), "How Foreign Investment Affects host countries", World Bank, Policy Research Working Paper n. 1745.

Borensztein, E., De Gregorio, J. and Lee, J.W. (1998), "How does Foreign Direct Investment Affect Economic Growth?", Journal of International Economics, vol. 45, n. 1, pp. 115-135.

Brülhart, M.(1998), "Economic Geography, Industry Location and Trade: the evidence", The World Economy, vol. 21, n. 6, pp. 775-801

Hallet, M. (2000), "Regional Specialisation and Concentration in the EU", Economic papers, n. 141, march.

Hansen, N. (1993), "Producer Services, Productivity and Metropolitan Income", Review of Regional Studies, winter, vol. 23 (3), pp. 255-264.

Hanson, G.H. (1998), "Regional Adjustment to Trade Liberalisation", Regional Science and Urban Economics, vol. 28, pp. 419-444.

Hardy, J. (1998), "Cathedrals in the Desert? Transnationals, Corporate Strategy and Locality in Wroclaw”, Regional Studies, vol. 32, n.7, pp. 639-652.

Holmes, T. (1995), "Localization of Industry and Vertical Disintegration", Staff Report, n. 190, Federal Reserve Bank of Minneapolis.

Konings, J. (2000) "The effects of direct foreign investment on domestic firms: evidence from firm level panel data in emerging economies", CEPR Discussion Paper N. 2586, London.

Krugman, P.R. (1991), Geography and Trade, MIT Press, Cambridge, MA.

Markusen, J. and Venables, A. (1997), "The impact of foreign direct investment on host economies processed", London School of Economics.

Markusen, J. and Venables, A. (1999), "Foreign direct investment as a catalyst for industrial development", European Economic Review, n. 43, pp. 335-356.

Marshall, A. (1890), Principles of Economics, London, MacMillan.

Martin, P. and Rogers, C.A. (1995), "Industrial location and public infrastructure", Journal of International Economics, n. 39, pp. 335-351.

Ottaviano, G. and Puga, D. (1998), "Agglomeration in the Global Economy: A Survey of the "New Economic Geography"”, The World Economy, vol. 21, n. 6, pp. 707-732. 
Repkine, A. and Walsh, P.P. (1999), "Evidence of European Trade and Investment U-Shaping Industrial Output in Bulgaria, Hungary, Poland and Romania", Journal of Comparative Economics, december, pp. 730-752.

Rodriguez-Clare, A. (1996), "Multinationals, Linkages, and Economic Development", The American Economic Review, vol. 86, n. 4, pp. 852-873.

Wheeler, D. and Mody, A. (1992), "International investment location decision: the case of US firms", Journal of International Economics, n. 33, pp. 57-76. 


\section{Annex 1. The regional classification of Polish regions}

Poland has revised its regional classification system since January 1999, passing from 49 nonhomogeneous voivodships to 16 new regions, in line with the NUTS-III equivalent classification system (this implied a change of some of the internal borders). The following list classifies the new regions with their administrative capital city and their peculiar location.

\begin{tabular}{|l|l|l|}
\hline Region & Capital city & location \\
\hline 1. Dolnoslaskie & Wroclaw & West border \\
\hline 2. Kujawsko & Bydgoscz & \\
\hline 3. Lubelskie & Lublin & Industrial pole \\
\hline 4. Lubuskie & Gorzow & West border \\
\hline 5. Lodzkie & Lodz & Industrial pole \\
\hline 6. Malopolskie & Krakow & \\
\hline 7. Mazowieckie & Warszawa & Capital region \\
\hline 8. Opolskie & Opole & \\
\hline 9. Podkaparckie & Rzeszow & \\
\hline 10. Podlaskie & Bialystock & \\
\hline 11. Pomorskie & Gdansk & Industrial pole \\
\hline 12. Slaskie & Katowice & Industrial pole \\
\hline 13. Swietokrzyskie & Kielce & \\
\hline 14. Warminsko & Olsztyn & Industrial pole \\
\hline 15. Wielkopolskie & Poznan & West border \\
\hline 16. Zachodnio Pomorskie & Szczecin & \\
\hline
\end{tabular}

\section{Annex 2 - The classification of industries}

\begin{tabular}{|l|l|l|}
\hline Industry & Consumption (Nace Rev. 1) & Intermediates (Nace Rev. 1) \\
\hline Food and beverages & 15 & $01,02,05 ; 2923,2953,2522$ \\
\hline Textiles and Clothing & $174,175,177,18$ & $171,172,173,176,2954,247$ \\
\hline Chemicals & $243,244,245,246$ & $23,241,242$ \\
\hline Constructions & 45 & $263-268,2922,2523,2812,2863,315$ \\
\hline Metal products & 282 & 27 \\
\hline Motor vehicles & 341,342 & $343,2914,251,314,3161$ \\
\hline Domestic appliances & 297 & $311,312,313,3162$ \\
\hline Leather and leather products & 193 & 191,192 \\
\hline Wood and Furniture & 36 & 20 \\
\hline Paper and paper product & $212,221,222$ & 211 \\
\hline
\end{tabular}




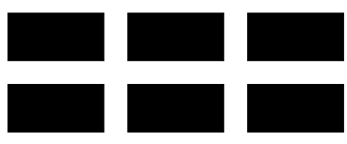

THE WiLliam DAVIDSON INSTITUTE

AT THE UNIVERSITY OF MICHIGAN BUSINESSSCHOOL

\section{DAVIDSON INSTITUTE WORKING PAPER SERIES - Most Recent Papers}

The entire Working Paper Series is available at: www.wdi.bus.umich.edu

CURRENT AS OF 4/4/01

\begin{tabular}{|c|c|c|}
\hline Publication & Authors & Date \\
\hline No. 367 A Multi-Task Theory of the State Enterprise Reform & $\begin{array}{l}\text { Chong-En Bai, David D. Li, } \\
\text { Zhigang Tao, and Yijiang Wang }\end{array}$ & Mar. 2001 \\
\hline No. 366 Confidence Building in Emerging Stock Markets & $\begin{array}{l}\text { Enrico C. Perotti, Luc Laeven, } \\
\text { and Pieter van Oijen }\end{array}$ & Dec. 2000 \\
\hline $\begin{array}{l}\text { No. } 365 \text { Incentive Contracting versus Ownership Reforms: Evidence } \\
\text { from China's Township and Village Enterprises }\end{array}$ & $\begin{array}{l}\text { Chun Chang, Brian McCall, and } \\
\text { Yijang Wang }\end{array}$ & Nov. 2000 \\
\hline $\begin{array}{l}\text { No. } 364 \text { Individual Pay and Outside Options: Evidence from the Polish } \\
\text { Labour Force Survey }\end{array}$ & $\begin{array}{l}\text { Fiona Duffy and Patrick Paul } \\
\text { Walsh }\end{array}$ & Mar. 2001 \\
\hline $\begin{array}{l}\text { No. } 363 \text { Investment, Credit Rationing and the Soft Budget Constraint: } \\
\text { Evidence from Czech Panel Data (revised Davidson Institute Working } \\
\text { Paper No. 60a) }\end{array}$ & Lubomír Lízal and Jan Svejnar & Feb. 2001 \\
\hline $\begin{array}{l}\text { No. } 362 \text { A Network Perspective on Inter-Organizational Transfer of } \\
\text { R\&D Capabilities: A Study of International Joint Ventures in Chinese } \\
\text { Automobile Industry }\end{array}$ & $\begin{array}{l}\text { Zheng Zhao, Jaideep Anand and } \\
\text { Will Mitchell }\end{array}$ & Feb. 2001 \\
\hline $\begin{array}{l}\text { No. } 361 \text { Network Restructuring and Firm Creation in East-Central } \\
\text { Europe: A Public-Private Venture }\end{array}$ & Gera & Dec. 2000 \\
\hline $\begin{array}{l}\text { No. } 360 \text { Responses of Private and Public Schools to Voucher Funding: } \\
\text { The Czech and Hungarian Experience }\end{array}$ & $\begin{array}{l}\text { Randall K. Filer and Daniel } \\
\text { Münich }\end{array}$ & Oct. 2000 \\
\hline $\begin{array}{l}\text { No. } 359 \text { Labor Market Uncertainty and Private Sector Labor Supply in } \\
\text { Russia }\end{array}$ & Steven Stillman & Sept. 2000 \\
\hline $\begin{array}{l}\text { No. } 358 \text { Russian Roulette-Expenditure Inequality and Instability in } \\
\text { Russia, 1994-1998 }\end{array}$ & Branko Jovanovic & Sept. 2000 \\
\hline No. 357 Dealing with the Bad Loans of the Chinese Banks & John P. Bonin and Yiping Huang & Jan. 2001 \\
\hline No. 356 Retail Banking in Hungary: A Foreign Affair? & John P. Bonin and István Ábel & Dec. 2000 \\
\hline $\begin{array}{l}\text { No. } 355 \text { Optimal Speed of Transition: Micro Evidence from the Czech } \\
\text { Republic }\end{array}$ & $\begin{array}{l}\text { Stepan Jurajda and Katherine } \\
\text { Terrell }\end{array}$ & Dec. 2000 \\
\hline No. 354 Political Instability and Growth in Dictatorships & $\begin{array}{l}\text { Jody Overland, Kenneth L. } \\
\text { Simons and Michael Spagat }\end{array}$ & Nov. 2000 \\
\hline No. 353 Disintegration and Trade & Jarko Fidrmuc and Jan Fidrmuc & Nov. 2000 \\
\hline $\begin{array}{l}\text { No. } 352 \text { Social Capital and Entrepreneurial Performance in Russia: A } \\
\text { Panel Study }\end{array}$ & Bat Batjargal & Dec. 2000 \\
\hline $\begin{array}{l}\text { No. 351 Entrepreneurial Versatility, Resources and Firm Performance in } \\
\text { Russia: A Panel Study }\end{array}$ & Bat Batjargal & Dec. 2000 \\
\hline $\begin{array}{l}\text { No. } 350 \text { The Dynamics of Entrepreneurial Networks in a Transitional } \\
\text { Economy: The Case of Russia }\end{array}$ & Bat Batjargal & Dec. 2000 \\
\hline $\begin{array}{l}\text { No. } 349 \text { R\&D and Technology Spillovers via FDI: Innovation and } \\
\text { Absorptive Capacity }\end{array}$ & Yuko Kinoshita & Nov. 2000 \\
\hline $\begin{array}{l}\text { No. } 348 \text { Microeconomic aspects of Economic Growth in Eastern } \\
\text { Europe and the Former Soviet Union, } 1950-2000\end{array}$ & Sergei Guriev and Barry W. Ickes & Nov. 2000 \\
\hline $\begin{array}{l}\text { No. } 347 \text { Effective versus Statutory Taxation: Measuring Effective Tax } \\
\text { Administration in Transition Economies }\end{array}$ & $\begin{array}{l}\text { Mark E. Schaffer and Gerard } \\
\text { Turley }\end{array}$ & Nov. 2000 \\
\hline $\begin{array}{l}\text { No. } 346 \text { Objectives and Constraints of Entrepreneurs: Evidence from } \\
\text { Small and Medium Size Enterprises in Russia and Bulgaria }\end{array}$ & $\begin{array}{l}\text { Francesca Pissarides, Miroslav } \\
\text { Singer and Jan Svejnar }\end{array}$ & Oct. 2000 \\
\hline No. 345 Corruption and Anticorruption in the Czech Republic & $\begin{array}{l}\text { Lubomír Lízal and Evžen } \\
\text { Kočenda }\end{array}$ & Oct. 2000 \\
\hline
\end{tabular}




\begin{tabular}{|c|c|c|}
\hline No. 344 The Effects of Direct Foreign Investment on Domestic Firms & Jozef Konings & Oct. 2000 \\
\hline No. 343 On the Identification of Relative Wage Rigidity Dynamics & Patrick A. Puhani & Oct. 2000 \\
\hline $\begin{array}{l}\text { No. } 342 \text { The Determinants of Foreign Direct Investment in Transition } \\
\text { Economies }\end{array}$ & Alan A. Bevan and Saul Estrin & Oct. 2000 \\
\hline No. 341 The Global Spread of Stock Exchanges, 1980-1998 & Klaus Weber and Gerald F. Davis & Nov. 2000 \\
\hline $\begin{array}{l}\text { No. } 340 \text { The Costs and Benefits of Euro-isation in Central-Eastern } \\
\text { Europe Before or Instead of EMU Membership }\end{array}$ & D. Mario Nuti & Oct. 2000 \\
\hline No. 339 Debt Overhang and Barter in Russia & $\begin{array}{l}\text { Sergei Guriev, Igor Makarov and } \\
\text { Mathilde Maurel }\end{array}$ & Sept. 2000 \\
\hline $\begin{array}{l}\text { No. } 338 \text { Firm Performance and the Political Economy of Corporate } \\
\text { Governance: Survey Evidence for Bulgaria, Hungary, Slovakia and } \\
\text { Slovenia }\end{array}$ & $\begin{array}{l}\text { Patrick Paul Walsh and Ciara } \\
\text { Whela }\end{array}$ & July 2000 \\
\hline No. 337 Investment and Instability & $\begin{array}{l}\text { Nauro F. Campos and Jeffrey B. } \\
\text { Nugent }\end{array}$ & May 2000 \\
\hline $\begin{array}{l}\text { No. } 336 \text { The Evolution of the Insurance Sector in Central and } \\
\text { Eastern Europe and the former Soviet Union }\end{array}$ & Robert B.K. Pye & Aug. 2000 \\
\hline $\begin{array}{l}\text { No. } 335 \text { Institutional Technology and the Chains of Trust: Capital } \\
\text { Markets and Privatization in Russia and the Czech Republic }\end{array}$ & Bruce Kogut and Andrew Spicer & Aug. 2000 \\
\hline No. 334 The Evolution of Market Integration in Russia & $\begin{array}{l}\text { Daniel Berkowitz and David N. } \\
\text { DeJong }\end{array}$ & Aug. 2000 \\
\hline No. 333 Efficienc & László Halpern and Gábor Körösi & July 2000 \\
\hline No. 332 Search-Money-and-Barter Models of Financial Stabilization & $\begin{array}{l}\text { lenko and S.Z. } \\
\text { ii }\end{array}$ & July 2000 \\
\hline $\begin{array}{l}\text { No. } 331 \text { Worker Training in a Restructuring Economy: Evidence from } \\
\text { the Russian Transition }\end{array}$ & $\begin{array}{l}\text { rger, John S. Earle } \\
\text { Sabirianova }\end{array}$ & Aug. 2000 \\
\hline $\begin{array}{l}\text { No. } 330 \text { Economic Development in Palanpur 1957-1993: A Sort of } \\
\text { Growth }\end{array}$ & Peter Lanj & Aug. 2000 \\
\hline $\begin{array}{l}\text { No. } 329 \text { Trust, Organizational Controls, Knowledge Acquisition from } \\
\text { the Foreign Parents, and Performance in Vietnamese International Joint } \\
\text { Ventures }\end{array}$ & $\begin{array}{l}\text { Marjorie A. Lyles, Le Dang } \\
\text { Doanh, and Jeffrey Q. Barden }\end{array}$ & June 2000 \\
\hline $\begin{array}{l}\text { No. } 328 \text { Comparative Advertising in the Global Marketplace: The } \\
\text { Effects of Cultural Orientation on Communication }\end{array}$ & $\begin{array}{l}\text { Zeynep C } \\
\text { Durairaj }\end{array}$ & Aug. 2000 \\
\hline No. 327 Post Privatization Enterprise Restructuring & Morris Bornstein & July 2000 \\
\hline No. 326 Who is Afraid of Political Instability? & $\begin{array}{l}\text { Nauro F. Campos and Jeffrey B. } \\
\text { Nugent }\end{array}$ & July 2000 \\
\hline No. 325 Busin & Raja Kali & June 2000 \\
\hline $\begin{array}{l}\text { No. } 324 \text { Restructuring with What Success? A Case Study of Russian } \\
\text { Firms }\end{array}$ & Susan Linz & July 2000 \\
\hline $\begin{array}{l}\text { No. } 323 \text { Priorities and Sequencing in Privatization: Theory and } \\
\text { Evidence from the Czech Republic }\end{array}$ & $\begin{array}{l}\text { Nandini Gupta, John C. Ham and } \\
\text { Jan Svejnar }\end{array}$ & May 2000 \\
\hline $\begin{array}{l}\text { No. } 322 \text { Liquidity, Volatility, and Equity Trading Costs Across } \\
\text { Countries and Over Time }\end{array}$ & $\begin{array}{l}\text { Ian Domowitz, Jack Glen and } \\
\text { Ananth Madhavan }\end{array}$ & Mar. 2000 \\
\hline $\begin{array}{l}\text { No. } 321 \text { Equilibrium Wage Arrears: A Theoretical and Empirical } \\
\text { Analysis of Institutional Lock-In }\end{array}$ & $\begin{array}{l}\text { John S. Earle and Klara Z. } \\
\text { Sabirianova }\end{array}$ & Oct. 2000 \\
\hline No. 320 Rethinking Marketing Programs for Emerging Markets & $\begin{array}{l}\text { Niraj Dawar and Amitava } \\
\text { Chattopadhyay }\end{array}$ & June 2000 \\
\hline $\begin{array}{l}\text { No. } 319 \text { Public Finance and Low Equilibria in Transition Economies: } \\
\text { the Role of Institutions }\end{array}$ & $\begin{array}{l}\text { Daniel Daianu and Radu } \\
\text { Vranceanu }\end{array}$ & June 2000 \\
\hline $\begin{array}{l}\text { No. } 318 \text { Some Econometric Evidence on the Effectiveness of Active } \\
\text { Labour Market Programmes in East Germany }\end{array}$ & $\begin{array}{l}\text { Martin Eichler and Michael } \\
\text { Lechner }\end{array}$ & June 2000 \\
\hline No. 317 A Model of Russia's "Virtual Economy" & R.E Ericson and B.W Ickes & May 2000 \\
\hline $\begin{array}{l}\text { No. } 316 \text { Financial Institutions, Financial Contagion, and Financial } \\
\text { Crises }\end{array}$ & $\begin{array}{l}\text { Haizhou Huang and Chenggang } \\
\mathrm{Xu}\end{array}$ & Mar. 2000 \\
\hline $\begin{array}{l}\text { No. } 315 \text { Privatization versus Regulation in Developing Economies: T } \\
\text { Case of West African Banks }\end{array}$ & $\begin{array}{l}\text { Jean Paul Azam, Bruno Biais, and } \\
\text { Magueye Dia }\end{array}$ & Feb. 2000 \\
\hline
\end{tabular}




\begin{tabular}{|c|c|c|}
\hline $\begin{array}{l}\text { No. } 314 \text { Is Life More Risky in the Open? Household Risk-Coping and } \\
\text { the Opening of China's Labor Markets }\end{array}$ & John Giles & Apr. 2000 \\
\hline $\begin{array}{l}\text { No. } 313 \text { Networks, Migration and Investment: Insiders and Outsiders in } \\
\text { Tirupur's Production Cluster }\end{array}$ & $\begin{array}{l}\text { Abhijit Banerjee and Kaivan } \\
\text { Munshi }\end{array}$ & Mar. 2000 \\
\hline $\begin{array}{l}\text { No. } 312 \text { Computational Analysis of the Impact on India of the Uruguay } \\
\text { Round and the Forthcoming WTO Trade Negotiations }\end{array}$ & $\begin{array}{l}\text { Rajesh Chadha, Drusilla K. } \\
\text { Brown, Alan V. Deardorff and } \\
\text { Robert M. Stern }\end{array}$ & Mar. 2000 \\
\hline No. 311 Subsidized Jobs for Unemployed Workers in Slovakia & Jan. C. van Ours & May 2000 \\
\hline No. 310 Determinants of Managerial Pay in the Czech Republic & $\begin{array}{l}\text { Tor Eriksson, Jaromir Gottvald } \\
\text { and Pavel Mrazek }\end{array}$ & May 2000 \\
\hline $\begin{array}{l}\text { No. } 309 \text { The Great Human Capital Reallocation: An Empirical Analysis } \\
\text { of Occupational Mobility in Transitional Russia }\end{array}$ & Klara Z. Sabirianova & Oct. 2000 \\
\hline No. 308 Economic Development, Legality, and the Transplant Effect & $\begin{array}{l}\text { Daniel Berkowitz, Katharina } \\
\text { Pistor, and Jean-Francois Richard }\end{array}$ & Feb. 2000 \\
\hline $\begin{array}{l}\text { No. } 307 \text { Community Participation, Teacher Effort, and Educational } \\
\text { Outcome: The Case of El Salvador's EDUCO Program }\end{array}$ & Yasuyuki Sawada & Nov. 1999 \\
\hline No. 306 Gender Wage Gap and Segregation in Late Transition & Stepan Jurajda & May 2000 \\
\hline $\begin{array}{l}\text { No. } 305 \text { The Gender Pay Gap in the Transition from Communism: } \\
\text { Some Empirical Evidence }\end{array}$ & Andrew Newell and Barry Reilly & May 2000 \\
\hline No. 304 Post-Unification Wage Growth in East Germany & Jennifer Hunt & Nov. 1998 \\
\hline $\begin{array}{l}\text { No. } 303 \text { How Does Privatization Affect Workers? The Case of the } \\
\text { Russian Mass Privatization Program }\end{array}$ & Elizabeth Brainerd & May 2000 \\
\hline $\begin{array}{l}\text { No. } 302 \text { Liability for Past Environmental Contamination and } \\
\text { Privatization }\end{array}$ & Dietrich Earnhart & Mar. 2000 \\
\hline No. 301 Varieties, Jobs and EU Enlargement & $\begin{array}{l}\text { Tito Boeri and Joa } \\
\text { Martins }\end{array}$ & 000 \\
\hline No. 300 Employer Size Effec & Todd Idson & Apr. 2000 \\
\hline $\begin{array}{l}\text { No. } 299 \text { Information Complements, Substitutes, and Strategic Product } \\
\text { Design }\end{array}$ & $\begin{array}{l}\text { Geoffrey G. Parker and Marshall } \\
\text { W. Van Alstyne }\end{array}$ & Mar. 2000 \\
\hline $\begin{array}{l}\text { No. } 298 \text { Markets, Human Capital, and Inequality: Evidence from Rural } \\
\text { China }\end{array}$ & $\begin{array}{l}\text { Dwayne Benjamin, Loren Brandt, } \\
\text { Paul Glewwe, and Li Guo }\end{array}$ & May 2000 \\
\hline No. 297 Corporate Governance in the Asian Financial Crisis & $\begin{array}{l}\text { Simon Johnson, Peter Boone, } \\
\text { Alasdair Breach, and Eric } \\
\text { Friedman }\end{array}$ & Nov. 1999 \\
\hline No. 296 Competition and Firm Perfor & J. David Brown and John S. Earle & Mar. 2000 \\
\hline No. 295 Wage Determination in Russia: An Econometric Investigation & $\begin{array}{l}\text { Peter J. Luke and Mark E. } \\
\text { Schaffer }\end{array}$ & Mar. 2000 \\
\hline $\begin{array}{l}\text { No. } 294 \text { Can Banks Promote Enterprise Restructuring?: Evidence From } \\
\text { a Polish Bank's Experience }\end{array}$ & John P. Bonin and Bozena Leven & Mar. 2000 \\
\hline No. 293 Why do Governments Sell Privatised Companies Abroad? & $\begin{array}{l}\text { Bernardo Bortolotti, Marcella } \\
\text { Fantini and Carlo Scarpa }\end{array}$ & Mar. 2000 \\
\hline $\begin{array}{l}\text { No. } 292 \text { Going Public in Poland: Case-by-Case Privatizations, Mass } \\
\text { Privatization and Private Sector Initial Public Offerings }\end{array}$ & Wolfgang Aussenegg & Dec. 1999 \\
\hline $\begin{array}{l}\text { No. 291a Institutional Technology and the Chains of Trust: Capital } \\
\text { Markets and Privatization in Russia and the Czech Republic }\end{array}$ & Bruce Kogut and Andrew Spicer & Feb. 2001 \\
\hline $\begin{array}{l}\text { No. } 291 \text { Institutional Technology and the Chains of Trust: Capital } \\
\text { Markets and Privatization in Russia and the Czech Republic }\end{array}$ & Bruce Kogut and Andrew Spicer & Mar. 1999 \\
\hline No. 290 Banking Crises and Bank Rescues: The Effect of Reputation & Jenny Corbett and Jan & Jan. 2000 \\
\hline $\begin{array}{l}\text { No. } 289 \text { Do Active Labor Market Policies Help Unemployed Workers to } \\
\text { Find and Keep Regular Jobs? }\end{array}$ & Jan C. van Ours & Feb. 2000 \\
\hline No. 288 Consumption Patterns of the New Elite in Zimbabwe & Russell Belk & Feb. 2000 \\
\hline $\begin{array}{l}\text { No. } 287 \text { Barter in Transition Economies: Competing Explanations } \\
\text { Confront Ukranian Data }\end{array}$ & $\begin{array}{l}\text { Dalia Marin, Daniel Kaufmann } \\
\text { and Bogdan Gorochowskij }\end{array}$ & Jan. 2000 \\
\hline $\begin{array}{l}\text { No. } 286 \text { The Quest for Pension Reform: Poland's Security through } \\
\text { Diversity }\end{array}$ & $\begin{array}{l}\text { Marek Góra and Michael } \\
\text { Rutkowski }\end{array}$ & Jan. 2000 \\
\hline
\end{tabular}


The entire Working Paper Series is available at: www.wdi.bus.umich.edu

\begin{tabular}{|c|c|c|}
\hline No. 285 Disorganization and Financial Collapse & $\begin{array}{l}\text { Dalia Marin and Monika } \\
\text { Schnitzer }\end{array}$ & Oct. 1999 \\
\hline No. 284 Coordinating Changes in M-form and U-form Organizations & $\begin{array}{l}\text { Yingyi Qian, Gérard Roland and } \\
\text { Chenggang Xu }\end{array}$ & May 1999 \\
\hline $\begin{array}{l}\text { No. } 283 \text { Why Russian Workers Do Not Move: Attachment of Workers } \\
\text { Through In-Kind Payments }\end{array}$ & Guido Friebel and Sergei Guriev & Oct. 1999 \\
\hline No. 282 Lessons From Fiascos in Russian Corporate Governance & $\begin{array}{l}\text { Merritt B. Fox and Michael A. } \\
\text { Heller }\end{array}$ & Oct. 1999 \\
\hline $\begin{array}{l}\text { No. } 281 \text { Income Distribution and Price Controls: Targeting a Social } \\
\text { Safety Net During Economic Transition }\end{array}$ & $\begin{array}{l}\text { Michael Alexeev and James } \\
\text { Leitzel }\end{array}$ & Mar. 1999 \\
\hline $\begin{array}{l}\text { No. 280: Starting Positions, Reform Speed, and Economic Outcomes in } \\
\text { Transitioning Economies }\end{array}$ & William Hallagan and Zhang Jun & Jan. 2000 \\
\hline No. 279: The Value of Prominent Directors & $\begin{array}{l}\text { Yoshiro Miwa \& } \\
\text { Ramseyer }\end{array}$ & Oct. 1999 \\
\hline No. 278: The System Paradigm & János Kornai & Apr. 1998 \\
\hline $\begin{array}{l}\text { No. 277: The Developmental Consequences of Foreign Direct } \\
\text { Investment in the Transition from Socialism to Capitalism: The } \\
\text { Performance of Foreign Owned Firms in Hungary }\end{array}$ & ence Peter King & Sept. 1999 \\
\hline $\begin{array}{l}\text { No. 276: Stability and Disorder: An Evolutionary Analysis of Russia's } \\
\text { Virtual Economy }\end{array}$ & $\begin{array}{l}\text { Clifford Gaddy and Barry W. } \\
\text { Ickes }\end{array}$ & Nov. 1999 \\
\hline $\begin{array}{l}\text { No. 275: Limiting Government Predation Through Anonymous } \\
\text { Banking: A Theory with Evidence from China. }\end{array}$ & $\begin{array}{l}\text { Chong-En Bai, David D. Li, } \\
\text { Yingyi Qian and Yijiang Wang }\end{array}$ & July 1999 \\
\hline No. 274: Transition with Labour Supply & Tito Boeri & Dec. 1999 \\
\hline $\begin{array}{l}\text { No. 273: Sectoral Restructuring and Labor Mobility: A Cor } \\
\text { Look at the Czech Republic }\end{array}$ & Vit Sorm and Kath & Nov. 1999 \\
\hline $\begin{array}{l}\text { No. 272: Published in: Journal of Comparative Economics "Returns to } \\
\text { Human Capital Under the Communist Wage Grid and During the } \\
\text { Transition to a Market Economy" Vol. 27, pp. 33-60 } 1999 .\end{array}$ & $\begin{array}{l}\text { ch, Jan Svejnar and } \\
\text { rrell }\end{array}$ & ct. 1999 \\
\hline $\begin{array}{l}\text { No. 271: Barter in Russia: Liquidity Shortage Versus Lack of } \\
\text { Restructuring }\end{array}$ & $\begin{array}{l}\text { e Brana and Mathilde } \\
\text { el }\end{array}$ & June 1999 \\
\hline $\begin{array}{l}\text { No. 270: Tests for Efficient Financial Intermediation with Application to } \\
\text { China }\end{array}$ & Albert Park and Kaja Sehrt & Mar. 1999 \\
\hline $\begin{array}{l}\text { No. 269a: Russian Privatization and Corporate Governance: What Went } \\
\text { Wrong? }\end{array}$ & $\begin{array}{l}\text { Berı } \\
\text { and }\end{array}$ & May 2000 \\
\hline $\begin{array}{l}\text { No. 269: Russian Privatization and Corporate Governance: What Went } \\
\text { Wrong? }\end{array}$ & $\begin{array}{l}\text { Bernard Black, Reinier Kraakman } \\
\text { and Anna Tarassova }\end{array}$ & Sept. 1999 \\
\hline No. 268: Are Russians Really Ready for Capitalism? & Susan Linz & Sept. 1999 \\
\hline No. 267: Do Stock Markets Promote Economic Growth? & $\begin{array}{l}\text { Randall K. Filer, Jan Han } \\
\text { and Nauro Campos }\end{array}$ & Sept. 1999 \\
\hline $\begin{array}{l}\text { No. 266: Objectivity, Proximity and Adaptability in Corporate } \\
\text { Governance }\end{array}$ & $\begin{array}{l}\text { Arnoud W.A Boot and Jonathan } \\
\text { R. Macey }\end{array}$ & Sept. 1999 \\
\hline $\begin{array}{l}\text { No. 265: When the Future is not What it Used to Be: Lessons from the } \\
\text { Western European Experience to Forecasting Education and Training in } \\
\text { Transitional Economies }\end{array}$ & $\begin{array}{l}\text { Nauro F. Campos, Gerard } \\
\text { Hughes, Stepan Jurajda, and } \\
\text { Daniel Munich }\end{array}$ & Sept. 1999 \\
\hline $\begin{array}{l}\text { No. 264: The Institutional Foundation of Foreign-Invested Enterprises } \\
\text { (FIEs) in China }\end{array}$ & Yasheng Huang & Sept. 1999 \\
\hline $\begin{array}{l}\text { No. 263: The Changing Corporate Governance Paradigm: Implications } \\
\text { for Transition and Developing Countries }\end{array}$ & $\begin{array}{l}\text { Erik Bergl } \\
\text { von Thadd }\end{array}$ & June 1999 \\
\hline No. 262: Law Enforcement and Transition & $\begin{array}{l}\text { Gerard Roland and Thierry } \\
\text { Verdier }\end{array}$ & May 1999 \\
\hline $\begin{array}{l}\text { No. 261: Soft Budget Constraints, Pecuniary Externality, and the Dual } \\
\text { Track System }\end{array}$ & Jiahua Che & June 2000 \\
\hline $\begin{array}{l}\text { No. 260: Missing Market in Labor Quality: The Role of Quality Markets } \\
\text { in Transition }\end{array}$ & Gary H. Jefferson & July 1999 \\
\hline $\begin{array}{l}\text { No. 259: Do Corporate Global Environmental Standards in Emerging } \\
\text { Markets Create or Destroy Market Value }\end{array}$ & $\begin{array}{l}\text { Glen Dowell, Stuart Hart and } \\
\text { Bernard Yeung }\end{array}$ & June 1999 \\
\hline
\end{tabular}

